\title{
Quantification of $\mathrm{CO}_{2}$ Emissions from Vehicles and Possible Remedial Strategies in Faisalabad City
}

\author{
Muhammad Usman ${ }^{1 *}$, Hafsa Yasin ${ }^{1}$, Haroon Rashid ${ }^{1}$ and Abdul Nasir $^{1}$
}

${ }^{1}$ Department of Structures and Environmental Engineering, University of Agriculture Faisalabad, Pakistan *Corresponding author's e-mail:

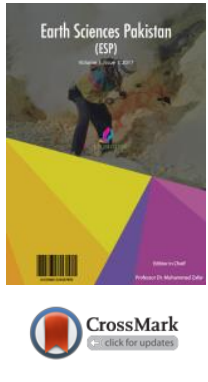

musman03@hotmail.com

This is an open access article distributed under the Creative Commons Attribution License, which permits unrestricted use, distribution, and reproduction in any medium, provided the original work is properly cited

\section{ARTICLE DETAILS}

Article history:

\section{Received 26 October 2016}

Accepted 10 December 2016

Available online 9 January 2017

Keywords:

$\mathrm{CO}_{2}$ Emissions, Tree plantation,

Vehicular emissions

\section{ABSTRACT}

Vehicular emissions pose a negative impact on the environment. Carbon dioxide is the main contributor to global warming which result due to greenhouse effect. The aim of this study is to quantify the $\mathrm{CO}_{2}$ emissions from transportation sector and determine the amount of trees required for compensating that quantified emissions. Road transport sector causes more urban airborne pollution than any other single human activity. Faisalabad is 3rd largest city of Pakistan where the situation is getting alarming due to industrial explosion, population growth and increasing high volume of traffic and it was selected for quantification of $\mathrm{CO}_{2}$. The practical application of emission could be seen last winter in a form of smog and it affected the visibility as well as causing irritation problem in eyes and nose. The study was carried out based on the emission factors of petrol and diesel i.e. $2.3 \mathrm{~kg} / \mathrm{L}$ and $2.7 \mathrm{~kg} / \mathrm{L}$ respectively. After collecting vehicular data, distances w.r.t vehicles type and fuels w.r.t distances were determined .With application of emission factors calculations on various amount of fuel used by various vehicles the summation of all emissions were determined. The concentration of $\mathrm{CO}_{2}$ emissions are 601.96 tons minimum, 894.4 tons averagely and 1190.23 tons maximum respectively. As our whole system of transportation is based on fossil fuel and complete shifting to clean fuel is time consuming and difficult so, plantation is the natural and more effective way of cleaning our air because they are natural eaters of $\mathrm{CO}_{2}$. To compensate the maximum emissions, it requires 20 million of plantations per year.

\section{Introduction}

Air is the basic matrix of life. The all types of living things need air for survival of life. Air pollution has developed into very alarming situation [1]. Besides natural sources of pollutants e.g. $\mathrm{CO}_{2}$ that are necessary for survival of plants, the major contributor in making situation a threat and alarming is the anthropogenic sources. Rapid industrialization and urbanization with increasing population cause an immense increase in $\mathrm{CO}_{2}$ level in ambient air that disturb the natural equilibrium in the atmosphere and thereby influencing human and its environment [2]. 3.7 million Preterm children annually expire; impaired immune system and mature people have more risk due to air pollution [3]. Present approximation discloses that quarter of earth's population must face poorly air pollution level and more than 2 million preterm dying of people annually by the effect of outdoor and indoor air pollution in cities and this situation is more common in the developing countries [4].

Some pollutants cause air pollution and contribute to greenhouse gases as well. Global warming and climate change are the world wide environmental concern that are seeking attention of many researchers, scientists and engineers. High global average temperature, rapid melting of snow and ice and rising average sea level are some of the confirmation and proof of changing climatic pattern [5]. The (IPCC) accounted a 1.1 to $6.4{ }^{\circ} \mathrm{C}$ expansion of the worldwide temperatures with increase in the sea level of 16.5 to $53.8 \mathrm{~cm}$ up to 2100 [6]. $\mathrm{CO}_{2}$ emissions which is a global pollutant is the main greenhouse gas that causes $58.8 \%$ of global warming and climate change [7]. The global concentration of carbon dioxide in the atmosphere, the primary driver of recent climate change has reached 409.01 parts per million (ppm) recent Monthly Average of $\mathrm{CO}_{2}$ in April 2017 for the first time in recorded history [8].

Carbon footprint can be defined as the summation of all $\mathrm{CO}_{2}$ emitted because of any activity including individual or community from anthropogenic sources in each time frame [9]. The top 10 largest emitter countries account for $67.6 \%$ of the world total $\mathrm{CO}_{2}$ emissions [10] Transport and energy sectors are the major air polluters. Road transport sector causes more air pollution than any other single human activity [11]
Trees are natural carbon eaters. All plants need $\mathrm{CO}_{2}$ to complete their life cycle. Trees digest $\mathrm{CO}_{2}$, remove and store carbon while delivering $\mathrm{O}_{2}$ back into the air. Due to this characteristic, it's a good option of climate change mitigation. Trees are more efficient in carbon sinking process while plants do less. Pine trees are best carbon absorbers [12]. In one year, an acre of mature trees absorbs the amount of $\mathrm{CO}_{2}$ produced which a car drive 26,000 miles [13].

Faisalabad is the third largest city in Pakistan after Karachi and situated at $31^{\circ} 25^{\prime} 0^{\prime \prime} \mathrm{N} / 73^{\circ} 5^{\prime} 0^{\prime \prime} \mathrm{E}$. It has a population of 6 million and it has high energy usage as it is a textile city. It has a murky transport system and high volume of traffic running on the roads. It causes load on air as well as creating noise pollution. The heavy density of automobiles cause different health diseases and sleeping disorder and stress issues etc. [14].

Previously, there existed four season with their regular intervals Precipitation occurred with its specific pattern. But the climatic conditions have changed gradually with increasing time and the interference of anthropogenic sources. Now-a-days the summers are long and intensive with maximum temperature $49^{\circ} \mathrm{C}(2016)$. The winters are short but extreme and intensive. These all changes are caused by Global warming and anthropogenic emissions are mainly responsible for global warming. For example, in November 2016 the smog phenomena occurred in major cities of Pakistan like Lahore, Faisalabad, and Gujranwala etc. It did not affect the visibility but also caused the irritation in eyes and nose. Due to change of climatic pattern Rainfall depletion, water scarcity, ground water depletion and various health problems occurs. They are especially harmful to citizens, children, and people with various disease. Secondly high amount of $\mathrm{CO}_{2}$ is also leading towards the addition of greenhouse gases which ultimately has consequences global warming that is the main concern now a days. In order to address these problems, it is necessary to quantify the carbon dioxide emissions which is the major component of GHG gases so that some sort of natural or engineering control will be applied. The aim of this study is to quantify the approximate $\mathrm{CO}_{2}$ emission from vehicles in Faisalabad and to determine the number of trees required to account $\mathrm{CO}_{2}$ emissions.

traffic volume on different roads in all possible paths. From this data and with some supposition the quantification can be performed. Third method includes registered vehicles data with some assumptions like fuel 
usage and distance coverage, the emission can be quantified.

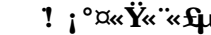

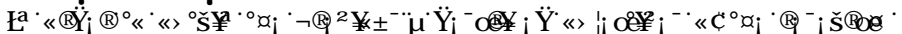

\section{ए}

1) Data collection (data of various vehicles and number of trees).

2) Development of three scenarios (minimum mileage, average mileage and maximum mileage)

3) Findings of respective mileage by conducting surveys or filling Performa's from different drivers at stations.

4) Specifying fuel according to determined distances (minimum, average and maximum)

5) Calculations $\{$ Emissions $(\mathrm{kg} /$ day $/$ vehicle $)=$ use liters $(\mathrm{L} / \mathrm{d}) \times$ Emission factor of that fuel (kg /

6) Total emissions $(\mathrm{kg} /$ day $)=$ emissions $(\mathrm{kg} /$ day $/$ vehicle $) \times$ no of vehicles $\}$ Summation of emissions from all vehicles.

7) Total emissions tons/day = summation of emission of vehicle type $1+$ vehicle type $2+\ldots . . . e t c$.

8) Determination of consumption of $\mathrm{CO} 2$ by already existing trees. Quantification of plants that are necessary for approximate balancing of maximum emission caused by transport sector.

There are two types of data required for this study number of Vehicles (Excise and transport department) and number of available trees (Punjab Horticulture Authority (PHA)).

Further, the interviews were conducted with different drivers of different vehicles to obtain the vehicular fuel consumption and its required distances. Then the specific distances and required fuel to cover that distance are taken into account for different types of vehicles. The distance scenarios and fuel required for that distance is based on survey conducted with different drivers of vehicles.

Three different scenarios including minimum scenario, average scenario and maximum scenario were developed in order to approach more accurate results. Minimum scenarios means the minimum distance cover by a particular vehicle and fuel require for that minimum distance. Average scenarios means the average distance cover by a particular vehicle and fuel require for that average distance. Likewise the maximum scenarios means the maximum distance cover by a particular vehicle and fuel require for that maximum distance.

Followed by the development of these scenarios, the calculation are performed based on the emission factors of petrol and diesel i.e. $2.3 \mathrm{~kg} / \mathrm{L}$ and $2.7 \mathrm{~kg} / \mathrm{L}$ respectively. This whole calculation process is repeated on various types of vehicles and then summation of emissions take place.

\section{Results and Discussion}

\subsection{Findings}

Data collected from different sources is presented in Table 1 and Table 2 .

Table 1: Data related to Vehicles travelling on roads in research area

\begin{tabular}{|c|l|c|c|c|}
\hline \multirow{2}{*}{ Sr. No. } & \multirow{2}{*}{ Types of Vehicles } & \multicolumn{3}{|c|}{ Number of Vehicles } \\
\cline { 3 - 5 } & & Petrol & Diesel & Total \\
\hline 1 & Bikes & 119268 & - & 119268 \\
\hline 2 & Cars & 18320 & 488 & 18808 \\
\hline 3 & Buses & - & 4121 & 4121 \\
\hline 4 & Wagons & 1178 & - & 1178 \\
\hline 5 & Motor Cap taxes & 1638 & - & 1638 \\
\hline 6 & Rickshaws & 5281 & - & 5281 \\
\hline 7 & Trucks & 0 & 4738 & 4738 \\
\hline 8 & Delivery van & 32 & 1845 & 1877 \\
\hline 9 & Tractors & 65 & 6538 & 6603 \\
\hline 10 & Ambulance & 27 & 119 & 146 \\
\hline 11 & Pickups & 1205 & 90 & 1295 \\
\hline
\end{tabular}

(Source: Excise and transport department)

Table 2: Availability of trees in study area

\begin{tabular}{|c|c|}
\hline $\begin{array}{c}\text { Trees } \\
\text { Category }\end{array}$ & $\begin{array}{c}\text { Available Quantities of } \\
\text { Tress }\end{array}$ \\
\hline Young & 350,000 \\
\hline Mature & 300,000 \\
\hline Old & 250,000 \\
\hline
\end{tabular}

(Source: Punjab Horticulture Authority)

\subsection{Compilation of Data based on three Scenarios}

The previous calculations performed in three scenarios with different types of vehicles each that compiles in total minimum, average and maximum emissions to find the total emissions.

Table 3: Calculation of $\mathrm{CO}_{2}$ emissions based on Three Different Scenarios

\begin{tabular}{|c|c|c|c|c|}
\hline Sr. No. & $\begin{array}{l}\text { Type of } \\
\text { Vehicles }\end{array}$ & $\begin{array}{l}\text { Minimum } \mathrm{CO}_{2} \\
\text { from Minimum } \\
\text { Distance (kg) }\end{array}$ & \begin{tabular}{|l|} 
Average $\mathrm{CO}_{2}$ \\
from Average \\
Distance (kg) \\
\end{tabular} & $\begin{array}{l}\text { Maximum } \mathrm{CO}_{2} \\
\text { from Maximum } \\
\text { distance (kg) }\end{array}$ \\
\hline 1 & Bikes & 109726.56 & 192021.48 & 274316.4 \\
\hline 2 & Cars & $\begin{array}{l}\text { Petrol } \\
70220.56 \\
\text { Diesel } \\
1756.8\end{array}$ & $\begin{array}{l}\text { Petrol } \\
122896.056 \\
\text { Diesel } \\
3074.4\end{array}$ & $\begin{array}{l}\text { Petrol } \\
175566.056 \\
\text { Diesel } \\
4392\end{array}$ \\
\hline 3 & Wagons & 12504.47 & 16668.7 & 20841.552 \\
\hline 4 & Buses & 178027.2 & 267040.8 & 356054.4 \\
\hline 5 & Rickshaws & 40452.66 & 48099.348 & 64132.464 \\
\hline 6 & Motor Cap Taxi & 23546.25 & 37674 & 47092.5 \\
\hline 7 & Trucks & 76755.6 & 89548.2 & 102340.8 \\
\hline 8 & Delivery van & $\begin{array}{l}\text { Petrol } \\
294.4 \\
\text { Diesel } \\
16605 \\
\end{array}$ & $\begin{array}{l}\text { Petrol } \\
368 \\
\text { Diesel } \\
20737.8 \\
\end{array}$ & $\begin{array}{l}\text { Petrol } \\
441.6 \\
\text { Diesel } \\
24807.87\end{array}$ \\
\hline 9 & Pickups & $\begin{array}{l}\text { Petrol } \\
14966.1 \\
\text { Diesel } \\
1603.8\end{array}$ & $\begin{array}{l}\text { Petrol } \\
19954.8 \\
\text { Diesel } \\
2138.4\end{array}$ & $\begin{array}{l}\text { Petrol } \\
24943.5 \\
\text { Diesel } \\
2673\end{array}$ \\
\hline 10 & Tractors & $\begin{array}{l}\text { Petrol } \\
272.09 \\
\text { Diesel } \\
52957.8 \\
\end{array}$ & $\begin{array}{l}\text { Petrol } \\
837.2 \\
\text { Diesel } \\
70675.78\end{array}$ & $\begin{array}{l}\text { Petrol } \\
1046.5 \\
\text { Diesel } \\
88263\end{array}$ \\
\hline 11 & Ambulance & \begin{tabular}{|l|} 
Petrol \\
382.15 \\
Diesel \\
1834.98 \\
\end{tabular} & \begin{tabular}{|l} 
Petrol \\
477.69 \\
Diesel \\
2293.13 \\
\end{tabular} & $\begin{array}{l}\text { Petrol } \\
566.352 \\
\text { Diesel } \\
2752.47 \\
\end{array}$ \\
\hline \multicolumn{2}{|c|}{$\sum \mathrm{CO}_{2}$ Emissions $=$ (tones) } & 601.906 & 894.45 & 1190.23 \\
\hline
\end{tabular}

\subsection{Graphical Representation of Scenarios}

Scenario 1: This scenario was developed for incorporating the minimum d distance covered by vehicles (bikes, cars, buses, wagons, rickshaws, motor cap taxes etc.) and it was computed to be emitting 601.906 tons of $\mathrm{CO}_{2}$ as shown in Fig. 1.

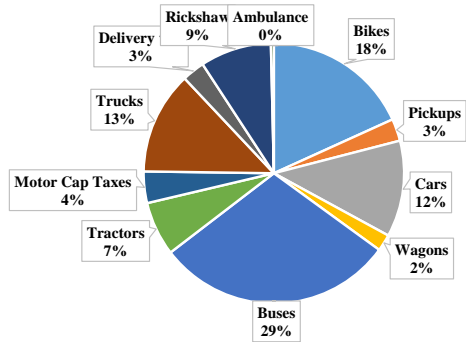

Fig 1: Percentage $\mathrm{CO}_{2}$ Emissions under Scenario 1

Scenario 2:It showed results based on average distance covered by vehicles (bikes, cars, buses,wagons, rickshaws, motor cap taxes etc.) and it was found that emissions are 894.45 tons of $\mathrm{CO}_{2}$ as shown in Fig. 2.

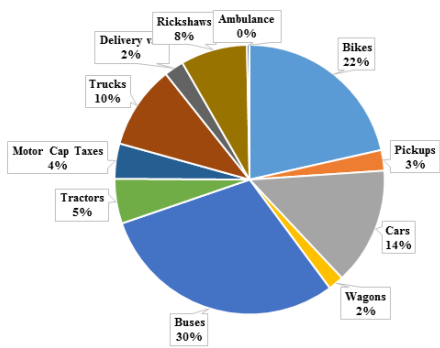

Fig 2: Percentage $\mathrm{CO}_{2}$ Emissions under Scenario 2

Scenario 3: it was developed to incorporate maximum distance travelled by vehicles (bikes,cars, buses, wagons, rickshaws, motor cap taxes etc.) as it was found that total emissions were 1190.23 tons of $\mathrm{CO}_{2}$ in this particular scenario as shown in Fig. 3. 


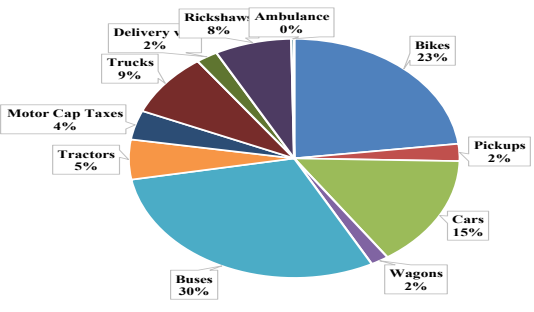

Fig 3: Percentage $\mathrm{CO}_{2}$ Emissions under Scenario 3

\subsection{Existing situation regarding availability of trees and tree plantation in study area}

The available trees data was collected from Punjab Horticultural Authority. Total amount of trees are approximately 9 lac which fall in three categories young, mature and old .They differ in sizes as well as in $\mathrm{CO} 2$ consumption. Trees above 40 benefits more than the younger trees.

Table 4: Available Trees in Faisalabad and Its Consumption of $\mathrm{CO}_{2}$

\begin{tabular}{|c|c|c|c|}
\hline $\begin{array}{c}\text { Trees } \\
\text { Category }\end{array}$ & $\begin{array}{c}\mathbf{C O}_{2} \text { Consumption } \\
\text { kg/Year }\end{array}$ & $\begin{array}{c}\text { Available Quantities } \\
\text { of Tress }\end{array}$ & $\begin{array}{c}\text { Consumption of CO} \\
\text { Available Trees }\end{array}$ \\
\hline Young & 5.90 & 350,000 & 5.6575 \\
\hline Mature & 22.72 & 300,000 & 18.6739 \\
\hline Old & 1000 & 250,000 & 684.4931 \\
\hline \multicolumn{2}{|c|}{ Total Consumption of $\mathrm{CO}_{2}$ by available trees } \\
\hline
\end{tabular}

\subsection{Discussion}

The above results give us the range of carbon dioxide emissions that lies between 601 tones to 1190 tons of $\mathrm{CO} 2$ emitted by vehicles per day. The value may range between them according to distance travelled by vehicles.

From the above graph the maximum contribution from transport sector in $\mathrm{CO} 2$ emissions is from the buses that operate on diesel that has high emission factor as compared to petrol. Improper maintenance of vehicles poses greater contribution to $\mathrm{CO} 2$ emissions then bike that are in large quantity. Likewise, the buses and wagons of old model create burden on atmosphere. Thirdly cars work on petrol and contribute to $15 \%$ of total emissions. Old model usually emits more amount than the new model that has clean flue gases. Rickshaws are usually in a very bad condition and they run on road without any proper maintenance. Same as other vehicles contribute in a lesser amount but it cannot be neglected.

The available trees in Faisalabad city is approximately 9 lac out of which 350,000 young trees, 300,000 mature trees and 250,000 old trees. By calculating the annual consumption of available trees i.e.708 tons/year which is only compensating the minimum scenarios that happens very rare. The available quantities of trees are not enough to meet the average and maximum scenarios. There is need to plant the more trees so that future generation may get some degree of clean environment. The carbon emissions and trees have to walk side by side. In coming days as population will increase it will increase traffic volume on roads and causing the increase load of $\mathrm{CO} 2$ in the air. After one or two years of planting young plants or trees they will enable to work as carbon absorber.

\section{Conclusion \\ पढ口س}

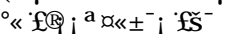

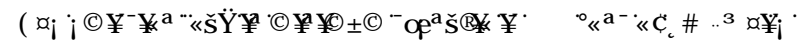
மாயس

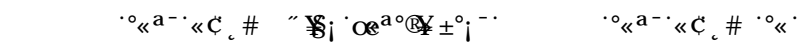

$\mathrm{CO}_{2}$ in minimum situation, 3.074 tons of $\mathrm{CO}_{2}$ in average mileage and 4.392 tons in maximum scenarios.

- Wagon contributes 12.50447 tons of $\mathrm{CO}_{2}$ to emissions in scenario minimum, 16.668 tons of $\mathrm{CO}_{2}$ in average scenario and 20.841552 tons of $\mathrm{CO}_{2}$ in maximum scenarios.

- Buses the main contributor in the $\mathrm{CO}_{2}$ emission that emits 178.027 tons of $\mathrm{CO}_{2}$ in minimum scenarios, 267.0408 tons of $\mathrm{CO}_{2}$ in average situation and 356.0544 tons of $\mathrm{CO}_{2}$ in maximum situation.

- Rickshaws emits 40.45266 tons of $\mathrm{CO}_{2}$ in minimum scenarios, 48.099 tons in average scenarios and 64.132464 tons of $\mathrm{CO}_{2}$ in maximum situation.

- Motor cap taxi contributes to load in the range of 23.54625 tons of $\mathrm{CO}_{2}$ in minimum scenarios, 37.674 tons of $\mathrm{CO}_{2}$ in average situation and 47.0925 tons of $\mathrm{CO}_{2}$ in maximum situation. Trucks emits 76.755 tons of $\mathrm{CO}_{2}$ in minimum situation, 89.5382 tons of $\mathrm{CO}_{2}$ in average scenarios and 102.3408 tons of $\mathrm{CO}_{2}$ in maximum situations.

- $\quad$ Pickups with petrol emits 14.9661 tons of $\mathrm{CO}_{2}$ in minimum situation, 19.9548 tons of $\mathrm{CO}_{2}$ in average scenarios and 24.9435 tons of $\mathrm{CO}_{2}$ in maximum situations while pickups with diesel emits 1.6 tons of $\mathrm{CO} 2$ in minimum scenarios, 2.1384 tons of $\mathrm{CO}_{2}$ in average scenarios and 2.673 tons of $\mathrm{CO}_{2}$ in maximum scenarios. Tractors with petrol emits 0.2720 tons of $\mathrm{CO}_{2}$ in minimum of situation, 0.8372 tons of $\mathrm{CO}_{2}$ in average scenarios and 1.0465 tons $\mathrm{CO}_{2}$ in maximum situations while tractors with diesel emits 52.957 tons of $\mathrm{CO}_{2}$ in minimum scenarios, 70.67578 tons of $\mathrm{CO}_{2}$ in average scenarios and 88.263 tons of $\mathrm{CO}_{2}$ in maximum scenarios.

- Ambulance with petrol emits 0.38215 tons of $\mathrm{CO}_{2}$ in minimum situation, 0.47769 tons of $\mathrm{CO}_{2}$ in average scenarios and 0.566352 tons of $\mathrm{CO}_{2}$ in maximum situations while ambulance with diesel emits 1.83498 tons of $\mathrm{CO}_{2}$ in minimum scenarios, 2.29313 tons of $\mathrm{CO}_{2}$ in average scenarios and 2.75247 tons of $\mathrm{CO} 2$ in maximum scenarios.

- The available young trees are absorbing 5.6575 tons/year, mature trees are compensating 18.6739 tons/year and old trees are greatest absorber of all are absorbing 684.4931 tons/year.

- The total consumption of $\mathrm{CO}_{2}$ by available trees are 708 tons/ year.

\section{Remedial Strategies}

The minimum scenario of distance coverage happens very rare and the available trees are enough to meet the minimum emissions scenarios if it takes accounts only the vehicular emissions. The average and maximum emissions scenarios happens routinely so,

- $\quad$ To meet the average emission, it needs to plant 1.5 lac trees/year.

- The maximum emissions of $\mathrm{CO}_{2}$ need 20 million trees to plant as soon as possible to accommodate that emissions in a form of natural eaters.

- $\quad$ The cutting of trees should be strictly banned. In last 10 years over 10 crore trees were cut for widening roads and highways. It should be promoted to government level buildings as there are allot of empty spaces in these buildings that are enough good for planting trees to make clean environment.

- $\quad$ Campaign about trees should be promoted in primary level schools. In this way they get awareness about the importance of trees and plantations.

- $\quad$ Please do not wait for government to plant trees. Sowing seeds or planting trees does not cost much. Just collect seeds of Peeple, Mango, Lemon, Jamun, Neem, Custard Apple etc. Then dig twothree inch hole on open spaces, roadside, footpaths, highways, gardens and also in your society or bungalow. Bury these seeds in each hole with soil and then water them every two days in summer. In rainy season no need to water them. After 15 to 30 days small plants will be born. Let them mature and ensure they grow big.

Make planting trees and plants a national obligation in Pakistan to stop temperature from crossing $500 \mathrm{C}$ degrees. 


\section{References}

[1] Ali, A., Akhtar, S., Saqi, S.K. and Anwar, N. 2004. Air Pollution and its Consequences for Human Life in District Faisalabad. Pakistan Journal of Life and Social Sciences, 2(1); 43-45

[2] Niaz, Y., Jiti, Z. and Zhang, Yu. 2015. Influence of automotive emission on air pollution using GIS in Faisalabad, Pakistan. International journal of Agriculture and Biological Engineering, 8(1); 111-116

[3] WHO. 2014. Ambient (outdoor) air quality and health. Fact sheet N 313. Updated March 2014. WHO media Centre.http:// www.who.int/mediacentre/factsheets/fs313/en/

[4] WHO. 2005. Air Quality Guidelines, Global Update 2005.

[5] Munir, S. and Khan, A. Impact of Fossil Fuel Energy Consumption on $\mathrm{CO} 2$ Emissions: Evidence from Pakistan (1980-2010).http://pide.org.pk/psde/pdf/AGM29/paper/Sehar\% 20Munir

[6] IPCC.2007. Fourth Assessment Report (AR4). https:// www.ipcc.ch/publications_and_data/

publications_ipcc_fourth_assessment_report_synthesis_report.htm

[7] WHO.2007. A safer future: global public health security in the 21st century.http:www.who.int/whr/2007/en/

[8] https://www.esrl.noaa.gov/gmd/ccgg/trends/ (last accessed on 26-05-17)

[9] https://en.wikipedia.org/wiki/Carbon_footprint (last accessed on 26-05-17)

[10] https://en.wikipedia.org/wiki/ List_of_countries_by_carbon_dioxide_emissions (last accessed on 27-05-17)

[11] Qadir, N.F. Air Quality in Urban areas in Pakistan Vs Transport Planning: Issues and Management tools. http:// kitakyushu.iges.or.jp/docs/mtgs/seminars/theme/uaqm/

Presentations/NQadir1.pdf

[12] ThoughtCo. 2017. https://www.thoughtco.com/whichtrees-offset-global-warming-1204209 (last accessed on 28-05-17)

[13] Tree people. 2017. https://www.treepeople.org/ resources/tree-benefits (last accessed on 28-05-17)

[14] Niaz, Y., Iqbal, M., Masood, N., Bokhari, T.H., Shehzad, M.A and Abbas, M. 2012. Temporal and spatial distribution of lead and total suspended particles in ambient air of Faisalabad, Pakistan. International Journal of Chemical and Biochemical Sciences, 2; 7-13. 